\title{
The Development of Energy Tourism Village in Indonesia: a Case Study in Nusa Penida
}

\author{
Tasdik Darmana, ${ }^{1, *}$, and Tony Koerniawan ${ }^{1}$ \\ ${ }^{1}$ Department of Electrical Engineering, PLN School of Engineering, Jakarta - Indonesia
}

\begin{abstract}
The potential for renewable energy in Nusa Penida and the surrounding islands such as solar power plant, wind power plants, Biofuel power plant and Sea-Current power plant as a source of power plant for Bali Island can be integrated with another tourism potential as marine tourism, culinary tour, cultural and religious tourism. The combination of various types of tourism will be more complete if added to tourism knowledge of renewable energy in one location on the Island of Nusa Penida. Using a qualitative approach in the form of a case study and a survey on the island of Nusa Penida and doing interviews with the community and government officials in the Regency of Klungkung, Nusa Penida has the potential to be developed into an integrated tourism area renewable energy field in Indonesia.
\end{abstract}

Keywords: Wind Power Plant; Solar PV Power Plant; Bio fuel Power Plant; Sea-Current Power Plant; Energy Tourism Village.

\section{Introduction}

Sustainable development according to the United Nations Conference on Environment and Development (UNCED) is a development that meets the needs of the current generation without reducing the ability of future generations to meet their needs. For the first time appear the concept of trying to meet the aspects of economic development and environmental conservation (ecologically). The concept has a broad meaning and becomes an umbrella for many concepts, policy, and development program which developed globally.

Sustainable tourism is tourism attempting to make an as low impact on the environment and local culture as possible, while helping to generate future employment for local people, thus, bringing a positive experience for local people, tourism companies and the tourists themselves.

The giving of the guarantee of the government in the acceleration of the power plant development as a set in the Presidential Regulation No. 4/2010 JO No. 48/2011 and the Regulation of the Minister of Finance No. 139/2011 to PT PLN (Persero) which is a state company that is responsible for the national electricity system and companies that distribute electrical energy directly to the consumer has taken several steps to test the use of renewable energy generators in Nusa Penida, Bali with steps pioneering is [1]:

a) The interconnection program of the "3-Nusa" in 2004, namely the island of Nusa Penida-Nusa Ceningan-Nusa Lembongan through the $20 \mathrm{kV}$ Medium Transmission Line network of the Java-Bali system.

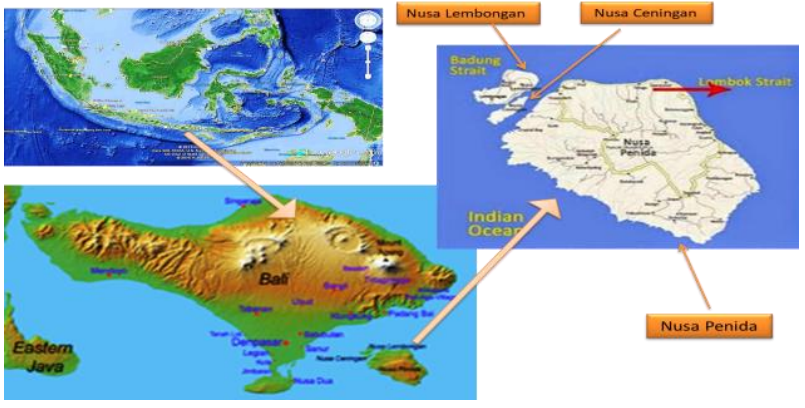

Fig. 1. The Map of Nusa Penida, Nusa Ceningan, Nusa Lembongan Islands

b) Construction of wind power plant system capacity of $85 \mathrm{~kW}$ at the Puncak Mundi,

c) Construction of solar power plant system capacity of $2 \times 30 \mathrm{~kW}$ at the Puncak Mundi,

d) Pilot program ABG (Academician, Business, and Government) conducted in 2006 in biofuel program (Jatropha curcas) and bio solar power plant test with a capacity of $25 \mathrm{~kW}$ in Nusa Lembongan,

e) Increasing the capacity of bio solar diesel from 800 $\mathrm{kW}$ to $2,500 \mathrm{~kW}$,

f) Bandung Institute of Technology has conducted research in Nusa Penida, Bali, in 2007 and 2009 with ocean current velocity of 0.5 to $3.2 \mathrm{~m} / \mathrm{s}$ and can generate electrical power of $200-400 \mathrm{~kW}$, and in the Lombok Strait with ocean velocity speeds of $1.8-2.4$ $\mathrm{m} / \mathrm{s}$ and can generate electrical power of 70 to 150 $\mathrm{kW}$ [2].

Bali is the best tourism destination in the world because it has various kind of tour plus with the

\footnotetext{
* Corresponding author: tasdik.darmana@sttpln.ac.id
} 
existence of various potential renewable energy then build tourism village energy into one of the commitment and concern of the government in developing the use of renewable energy as well as to develop the area of Nusa Penida as educational tourism area in the field of renewable energy.

\section{Concept of the Nusa Penida Energy Tourism Village}

The tourism development policy that is running the government is directed to the development of the tourism sector as a companion as a major foreign exchange earner and able to promote economic growth, increase revenues, empower people economy, expand jobs and the opportunity to work for the welfare of the people can be improved.

As stipulated in the Regulation of the Minister of Culture and Tourism No. : PM.26/UM.001/MKP/2010 about General Guidelines National Program for Community Empowerment (Program Nasional Pemberdayaan Masyarakat-PNPM) Mandiri Tourism through the Tourism Village that guidance in building tourism village must contain the concept, strategies, stages of the program and the implementation of PNPM Mandiri Tourism, in order to build community awareness and institutional strengthening so that the community can become perpetrators of tourism. PNPM Mandiri tourism was one of the efforts that are expected to be able to be a program to alleviate poverty through the tourism sector. Poverty problems require comprehensive handling and involving various sectors, in addition to the community itself as the subject. Therefore, poverty alleviation through the tourism sector also needed a strategy, instrument and programs appropriate action according to the characteristics of the problems.

Tourism has the characteristics of the potential and the strength of the attached, as follows:

a. In the tourism industry discounted rates are possible only when the tourists visiting the place where the tour products produced so that the positive impact of tourism in the form of tourist expenditure will flow directly to the community. Tourism is an instrument of the program and balancing the spread of the growth of a very effective.

b. Discounted Rates of tourism will be able to grow in a value-added chain to the front and to the back of the very long, so it is able to boost economic activities related to the very large.

c. The industry based on local resources. Characteristics of the tourism industry and culture that is very friendly on the absorption of local resources and attributes that intensive will be very effective in absorbing manpower and open business opportunities in the area.

Starting from nature and uniqueness and great potential for the strength of the tourism sector is very strategic to become the main driver of the economy of society. Therefore, the Ministry of Culture and Tourism will synergize the tourism development program based on the community through PNPM Mandiri Tourism by PNPM Independently coordinated by the ministry related to the welfare of the people and the village government administration.

The activities of PNPM Mandiri Tourism is focused on the development of the target areas that have the relevance of the function and influence with the elements of the tourist attraction in the form of the diversity of natural wealth, culture and the results of the man-made and tourism business facilities and creative industry is a prime mover in the activity of tourism in tourism village. Thus the PNPM Mandiri Tourism expected to give an impact on improving the welfare of the community in the tourism village and the surrounding area.

Nusa Penida plans to make a pilot island with renewable energy so that the "Go Green Go Clean" can be realized. This project ideally made the leading model as one form of development of the outermost islands and independence in the energy. This development is also expected to become the destination tourism village energy in Indonesia.

\section{Research Methodology}

In collecting the data, this study uses 2 (two) methods, which is through desk and field survey. The data collected through this method is intended to summarize the activities that have been conducted by a number of stakeholders involved in the Nusa Penida especially PT. PLN Area Bali and the district government of Klungkung, especially in the Nusa Penida. The data consists of reports related to renewable energy development di Nusa Penida and the Management Plan of the region that has been prepared for the time frame of 2000 - 2024. Data collection from the desk survey has helped identify the issues in the consulting process of formulating recommendations of the steps that need to be undertaken next by the stakeholders in developing eco-tourism in Nusa Penida [3].

The data collected through field visits was conducted through interviews and assessments using the village cooperatives for identifying landscape characters and elements that have an effect on the development of ecotourism in the Nusa Penida. Interviews and discussions were conducted the stakeholders involved, including among others the Head of village cooperatives Nusa Penida, Village Chief of Nusa Penida, Head of the Community Indonesia Go Green (IGG) Nusa Penida, residents of Nusa Penida. In the field trips conducted on September 2014 - Augustus 2015, other than directly visiting the villages within the Nusa Penida Island, we also visited a Bali traditional Tirta Yatra ceremony in the Puncak Mundi [4].

\section{Result and Discussion}

\subsection{Geographical Review}

Klungkung Regency is the smallest district from 9 Districts in Bali, located between $115^{\circ} 27^{\prime}-37^{\prime \prime} 8^{\circ} 49^{\prime}$ 
00 ". South Latitude with boundaries on the north side of Bangli Regency, East of Regency of Karangasem, the west side of the Gianyar regency, and the South Indian Ocean with area $315 \mathrm{Km}$.

Land in Klungkung Regency consists of rice fields 4.013 hectares, dry land 9.631 hectares, state forests 202 hectares, plantation 10.060 hectares and other 7.594 hectares.

The length of the beach Klungkung District around $90 \mathrm{~km}$ located at Klungkung mainland $20 \mathrm{Km}$ and the islands of Nusa Penida $70 \mathrm{Km}$. the surface of the ground on average, corrugated are generally not even most of the hills steep that barren and desolate. Only a small part of it is the lowlands. The level of slope of the land above $40 \%$ (rugged) is the area of $16.47 \mathrm{Km}^{2}$ or 5.32 percent of Klungkung Regency. The highest hill named "Puncak Mundi" which is located in the sub-district of Nusa Penida.

\subsection{Accessibility}

Island of Nusa Penida can be taken from the four namely through the port of Benoa using ships Quiksilver/Balihai taken 1 hour trip over the Sanur Harbor using the boat 1.5 hours trip. Through the port Kusamba using Jukung 1.5 hours trip. While if through Padangbai with sojourn Ships Boat that the distance of 1 hour trip.

\subsection{The surface of the Land}

The surface of the land on the generally wavy edge and hilly and some small is the lowlands. The level of slope of the land above $40^{\circ}$ (rugged) area of $16.47 \mathrm{~km} 2$ or 5.23 $\%$ from the area.

\subsection{Rainfall}

The average rainfall of the highest rainfall occurs in the sub-district of Banjarangkan $211.50 \mathrm{~mm}$ with average rainy days per month of 11.67 days, while the lowest in the sub-district of Nusa Penida.with the average rainfall of $75.75 \mathrm{~mm}$ and average rainy days 5.58 days.

On 2013 rainfall each month is relatively high, where the highest rainfall occurs in the month of December while the lowest in September. For the day of the highest rain occurred in January while the lowest in September.

\subsection{Population}

Based on the results of the projection of the number of the inhabitants of Klungkung Regency 2013 totaled 173.90 thousand souls.

The spread of the population is not evenly distributed in four sub-districts, namely $73.96 \%$ located on the mainland of Klungkung (Banjarangkan, Dawan, and Klungkung), while $26.04 \%$ located in the islands of Nusa Penida (Nusa Penida, Nusa Lembongan and Nusa Ceningan). Total Population in each sub-district namely Nusa Penida 48,560 life, Banjarangkan 39,463, Klungkung 57,614 life and Dawan 40.851 life.
The livelihoods of is the agriculture and fisheries sector is the main livelihoods by $6.68 \%$ percent spread on the coastal villages namely Suana, Batununggul, Kutampi Kaler, Ped, and Toyapakeh Village. In the Island of Lembongan $16.80 \%$ of the population engaged in the fisheries and Ceningan $12.88 \%$ remember the condition of topography and areas so that suitable developed is the agricultural sector and the tourism sector.

\subsection{The Blue Economy Concept in Nusa Penida}

With the potential of pointed out by region known as "3 Nusa Dua, namely, Nusa Ceningan Nusa Penida and Nusa Lembongan", the area around Nusa Penida have various potential renewable energy sources and the potential of the natural wealth of biodiversity.

The implementation of the Blue Economy in Nusa Penida is with inclined economic pattern to improve the economy of society that environmentally especially marine, namely with determine over zoning for or styling space area of Nusa Penida waters to integrate between the management and utilization of the region space in a balanced and harmonious that preceded by the socialization of the agreement of the government and the community related. Over zoning for this area that is specified according to the allocation, for example of the determination of the area of illegal fishing, diving area, area sacred areas, the area of the port and the main area. Step over zoning for then continued with the socialization to the public through the deliberation to the villages.

Table 1. Conservation Zone in Nusa Penida.

\begin{tabular}{|l|c|}
\hline Conservation Area in Nusa Penida & Wide (Ha) \\
\hline Core-Zone & 468.85 \\
\hline The Utilizing-Zone & \\
\hline a. Sub-zone marine tourism & $1,221.28$ \\
\hline b. Sub-Zona Ports & 35.15 \\
\hline Sustainable Fisheries Zone & \\
\hline a.Sub-Zona Traditional Fisheries & $16,915.71$ \\
\hline b.Sub-Zona marine Tourism & 905.24 \\
\hline Holy-Zone & 46.71 \\
\hline
\end{tabular}

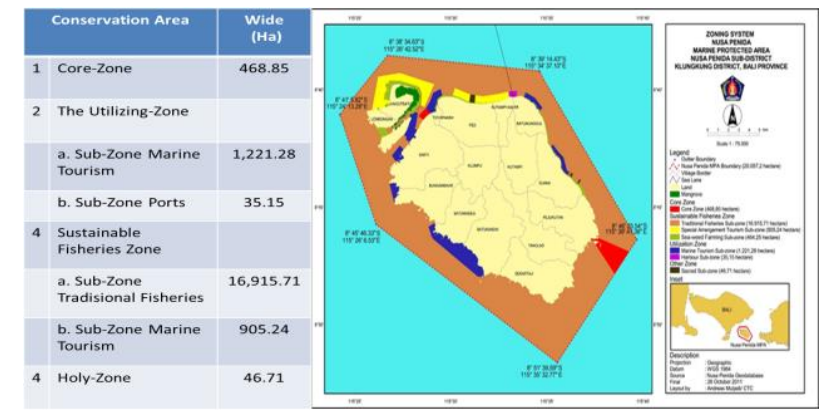

Fig. 2. Conservation Zone in Nusa Penida Island 
Table 2. Biodeversity in Nusa Penida

\begin{tabular}{|l|l|}
\hline \multicolumn{2}{|c|}{ The potential for Biodiversity in Nusa Penida } \\
\hline Coral reefs & $1,419 \mathrm{Ha}, 298$ types \\
\hline Fish & 576 type, 5 new type \\
\hline Mangroves & $230 \mathrm{Ha}, 13$ types \\
\hline seagrass beds & $108 \mathrm{Ha}, 8$ types \\
\hline Mega Fauna| & $\begin{array}{l}\text { Pari Manta fish, sea turtles, Sharks, } \\
\text { Pope, dolphins, dugong. }\end{array}$ \\
\hline & $\begin{array}{l}\text { One of the mega fauna sea which } \\
\text { became characteristic of the waters } \\
\text { of the Nusa Penida is fish Mola } \\
\text { mola (sunfish) with the size of an } \\
\text { average of approximately 2 m. Fish } \\
\text { Mola mola is often appeared in } \\
\text { Nusa Penida waters between July - } \\
\text { September each year }\end{array}$ \\
\hline
\end{tabular}

The concept of Blue Economy in Nusa Penida

a. The development of Marine Tourism:

In Nusa Penida there is a unique fish Mola Mola, Pari Manta and coral reefs to dive tourism attraction and there are 20 diving point in Nusa Penida waters. There are 230 hectares of mangrove with 13 in Nusa Lembongan types that can be developed for mangrove tour; water sports like fishing, sailing, and swimming can be developed to become part of the marine tourism.

b. Fishery and aquaculture Seaweed:

There are around 308 hectares area of seagrass in Nusa Penida with a production of 40-50 tons/month; food products processed products seaweed can be developed into various foods such as dodol, muffin, cracker eating, and seaweed juice. Seaweed can also produce substances that generator, cosmetics, and medicines; In Nusa Lembongan can be developed seaweed tour where tourists can join with farmers to grow the grass of the sea

c. Fishery: Nusa Penida waters is a place of legal fishing corn, tuna (Thunnini), kakap (Lutjanidae), tenggiri (Scomberomorini) and other fish, there are around 1000 fishermen in Nusa Penida; food product poles are fish such as shredded, cracker eating, meatballs, can be performed for tourists and as the Nusa Penida [5].

With the potential, tourism in Nusa Penida can be developed to become 3 tourist destination, namely:

1. Marine Tourism

2. Religious and Culture Tourism

3. Renewable Energy Touirsm

The potential for marine tourism owned by Nusa Penida very diverse, in addition to offering the tour under the sea amazing, Nusa Penida also has some very beautiful places to visit including the Beach Penida, Pura Batu Medawu, Pura Goa Giri Putri, Pura Dalem Ped, Puncak Mundi, and some of the sources of water in the south of Nusa Penida which offers the scenery with the cliff that tall between 50 - 200 meters.

Tourism Development religious aspects in the Island of Nusa Penida also can be done. Because it is an island with Niskala level (Godhead). Each month there is always Pemedek (visitors) overflowed this island, Tirta
Yatra Ceremony in a village, exactly in the village of Ped, Sampalan, Nusa Penida, there is a hypocrisy that is very popular all across the Bali, namely Pura Agung Training Ped located around 50 meters south of the lips of the oceans the Strait of Nusa Dua because of the influence of that very wide i.e. all across Bali Pura Agung Training Ped agreed as Pura Kahyangan Universe. Pura is always crowded pemedek for asking for salvation, prosperity, kerahayuan, and tranquility. Until this time, pura is well known as one of the spiritual tourism objects that most preferred.

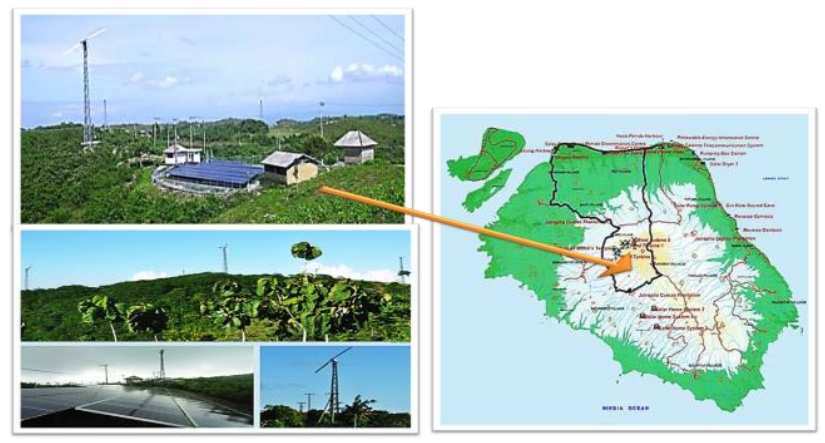

Fig. 3. Existing Condition of the PV and Wind Turbin in Puncak Mundi, Nusa Penida Island

\section{Conclusion}

The island of Nusa Penida is the only island which has a variety of potential renewable energy power plant a fully integrated hybrid and has great potential especially in the field of tourism and other potentials that does not exist in other areas in Bali, even Indonesia. There are dozens of tourism objects enclosed 3-Nusa is adjacent to the island of Bali, which has become a popular tourist destination in the whole world.

With the potential in the area of Nusa Penida, it has become the model of teaching for various parties such as:

- As a tourist destination marine-tourism, spiritualtourism, and renewable energy-tourism for students, the community and local government in the outermost islands and coastal areas.

- The world of business, as a model or pilot project for the development of electrical energy in the remote arear, the outermost islands (border areas) and the island of remote island.

- The Central Government and local government agencies in planning the power plants in the area of each according to their needs and the potential it possesses.

- Individuals, community, communities to do research and development to know how to work and the operation and maintenance of non-power plant fossils.

- Renewable energy sources have a positive impact on improving the tourism sector and see their role in tourism as a way to reduce the "carbon footprint" of the earth. 


\section{References}

1. Manik, C. Triseda, F.D. Wijaya, T. Juliandhy, Evaluation of Hybrid System Solar-Wind-Diesel in Nusa Penida Bali - Indonesia, International Journal of Scientific \& Engineering Research (2014)

2. T. Darmana, Nusa Penida Area Development as a Renewable Energy Resources for Bali Island, The International Conference of Vocational Studies on Applied Research (ICoVAR) Diponegoro University (2017)

3. R.A. Diantari, I. Pujotomo, Calculation of Electrical Energy with Solar Power Plant Design, International Seminar on Intelligent Technology and Its applications (ISITIA) (2017)

4. J. Purnomo, Bambang, Overview Business Concept for Nusa Penida Islands, IGG Komisariat Bali (2014)

5. BPS-Statistics of Klungkung Regency, Klungkung Regency in Figures 2016, (2016) 